\title{
PENGARUH BUDAYA ORGANISASI DAN KEPEMIMPINAN KEPALA SEKOLAH TERHADAP KOMITMEN ORGANISASI SERTA DAMPAKNYA TERHADAP KINERJA GURU SMK MUHAMMADIYAH SALATIGA
}

\author{
Oleh
}

\section{Samtono}

Dosen Tetap STIEPARI Semarang

\begin{abstract}
The purpose of the research is to examine and analyze the influence of the organizational culture and principle's leadhership and commitment organizational and its affect on teacher's performance in SMK Muhammadiyah Salatiga. The research was conducted to high school teacher of SMK Muhammadiyah Salatiga as many as 65 respondents.

The data obtained were processed using descriptive analysis and multiple regression analysis to determine the affect of independent variables on the dependent variables. The show that (1) The organizational culture has positive affect to commitment organizational, (2) The principle's leadhership has negative affect to commitment organizational, ( 3 ) The commitment organizational has positive affect to teacher's performance, (4) The principle's leadhership has negative affect to teacher's performance, (5) The commitment organizational has positive affect to teacher's performance, (6) The influence of organizational culture to the commitment organizational positive affect to teacher's performance, ( 7 ) The influence of the principle's leadhership to the commitment organizational positive affect the theachr's performance.
\end{abstract}

Keywords : The Organizational culture, Principle's Leadhership, Organizational Commitment, Teacher's Performance.

\section{PENDAHULUAN}

SMK Muhammadiyah berlokasi di Desa Soka Kecamatan Sidareja Salatiga berdiri sejak tahun pelajaran 1989/1990. Sekarang mulai tahun pelajaran 2017/2018 sudah memiliki peserta didik kurang lebih sebanyak 945 orang siswa, dan memiliki program keahlian atau jurusan ada empat program yang terdiri : Teknik Instalasi Tenaga Listrik ( TITL ); Teknik Kendaraan Ringan ～( TKR ); Teknik Permesinan ( TP ); Tata Busana ( TB ). Yang diasuh oleh sebanyak 65 orang guru yang terdiri dari Guru PNS yang diperbantukan 
3 orang; Guru Tetap Yayasan sebanyak 50 orang, dan guru Tidak Tetap sebanyak 12 orang.

Beberapa permasalahan yang ada pada SMK Muhammadiyah antara lain adalah:

1. Budaya Organisasi yang terjadi pada sekolah tersebut belum tercipta dan belum terbentuk dengan baik, mengingat sekolah tersebut sebagai sekolah yang besar dan berada pada lingkungan pembinaan lembaga Islam yang besar di Kota Salatiga, hal ini ditandai masih adanya guru datang tidak tepat waktu dan guru pulang sebelum waktunya disamping itu juga ada guru yang kurang peduli terhadap keberadaan peserta didik, sebagai contoh disaat Pembelajaran berlangsung ada beberapasiswa yang nongkrong sambil merokok disebelah sekolah dan ada yang nongkrong diwarung sebelah sekolah, namun ada beberapa guru yang tidak peduli tanpa disapa atau diperingatkan, guru bersikap acuh tak acuh saja.

2. Masih ada beberapa guru yang bersikap egois dan selalu mementingkan kepentingannya sendiri tanpa peduli dengan kepentingan lembaga atau organisasi disekolah sebagai contoh masih ada beberapa peseta didik/siswa maasuk sekolah tanpa seragam sekolah namun guru tidak memperingatkan dan guru sendiri juga tidak mengenakan seragam guru yang sudah menjadi ketentuan sekolah.

3. Kepala sekolah belum memerankan fungsi dan peran kepala sekolah secara maksimal, yaitu EMASLIM yang artinya kepala sekolah harus bisa memerankan fungsi dan perannya sebagai seorang : Edukator; sebagai Manajer, sebagai Administrator, sebagai Supervisor, sebagai leader, sebagai Inovator, dan sebagai Motivator

4. Belum semua guru dan karyawan memiliki komitmen yang kuat untuk membangun budaya organisasi yang baik dan kuat dilingkungan pendidikan muhammaduyah hal ini ditandai masih adanya guru dan karyawan dikala ada kegiatan Kemuhammadiyahan masih ada beberapa orang guru dan dan karyawan tidak mau berpartisipasi baik secara langsung maupun tidak langsung, baik secara formal maupun non formal, sebagai contoh setiap ada

Pengaruh Budaya Organisasi Dan Kepemimpinan Kepala Sekolah Terhadap Komitmen Organisasi Serta Dampaknya Terhadap Kinerja Guru SMK Muhammadiyah Salatiga (Samtono) 
kegiatan pengajian dan pembinaan dari Majelis maupun Pengurus Muhammadiyah Kota Salatiga tidak semua guru SMK dan Karyawan bisa mengikutinya dengan dalih berbagaialas an yang tidak jelas.

5. Guru SMK Muhammadiyah belum semuanya menunjukkan kinerja seperti yang diharapkan sesuai dengan Permendiknas Nomor 41 Tahun 2009 Tentang Penilaian Kinerja Guru. Sebagai contoh belum semua guru dalam melaksanaan pembelajaran membuat perencanaan dengan baik, dan belum semua guru dalam memberikan tugas-tugas atau ulangan -ulangan tidak semua dikoreksi dan hasilnya diberikan pada siswa/peserta didik, mana yang salah dan mana yang sudah benar kadang-kadang siswa tidak mengerti. Masih juga dijumpai beberapa siswa yang dalam ulangan harian belum mencapai Batas Tuntas sampai menghadapai ulangan selanjutnya belum diberikan bantuan Remedi. Sehingga siswa menjadi tertinggal dengan teman-teman yang lain.

\section{B. Rumusan Masalah Penelitian}

Berdasarkan uraian latar belakang tersebut diatas maka rumusan masalah Penelitian adalah sebagai berikut :

1. Apakah budaya organisasi mempengaruhi komitmen organisasi di SMK Muhammadiyah Salatiga ?

2. Apakah kepemimpinan kepala sekolah mempengaruhi komitmen organisasi di SMK Muhammadiyah Salatiga ?

3. Apakah budaya organisasi mempengaruhi kinerja guru di SMK MUhammadiyah Salatiga ?

4. Apakah kepemimpinan kepala sekolah mempengaruhi kinerja guru SMK Muhammadiyah Salatiga ?

5. Apakah komitmen organisasi mempengaruhi kinerja guru di SMK Muhammadiyah Salatiga ?

6. Apakah komitmen organisasi memediasi budaya organisasi terhadap kinerja guru SMK Muhammadiyah Salatiga ?

7. Apakah komitmen organisasi memediasi Kepemimpinan Kepala sekolah terhadap kinerja guru di SMK Muhammadiyah Salatiga ? 


\section{Tujuan Penelitian}

Adapun yang menjadi tujuan penelitian adalah sebagai berikut

1. Untuk menganalisis dan menjelaskan pengaruh budaya organisasi tehadap komitmen organisasi di SMK Muhammadiyah Salatiga

2. Untuk menganalisis dan menjelaskan pengaruh kepemimpinan kepala sekolah terhadap komitmen organisasi di SMK Muhammadiyah Salatiga

3. Untuk menganalisis dn menjelaskan pengaruh budaya organisasi terhadap kinerja guru di SMK Muhammadiyah Salatiga

4. Untuk menganalisis dan menjelaskan pengaruh kepemimpinan kepala sekolah terhadap kinerja guru di SMK Muhammadiyah

5. Untuk menganalisis dan menjelaskan apakah komitmen organisasi mempengaruhi kinerja guru di SMK Muhammadiyah Salatiga

6. Untuk menganalisis dan menjelaskan apakah komitmen organisasi memediasi budaya organisasi terhadap kinerja guru SMK Muhammadiyah Salatiga.

7. Untuk menganalisis dan menjelaskan apakah komitmen organisasi memediasi kepemimpinan kepala sekolah terhadap kinerja guru SMK Muhammadiyah Salatiga.

\section{PAPARAN TEORITIS}

1. Kepemimpinan Kepala Sekolah

Sekolah sebagai suatu lembaga pendidikan merupakan wadah untuk mencapai tujuan pembangunan nasional. Keberhasilan banyak tergantung pada sumber daya yang adadisekolah tersebut, yaitu kepala sekolah, guru, siswa, pegawai tata usaha, dan tenaga kependidikan lainnya. Kepemimpinan kepala sekolah sebagai Key person dlam menentukan keberhasilan kemajuan dan prestasi suatu sekolah, maka gerak langkah dan strategi kepemimpinan seorang kepala sekolah menjadi corong dan barometer kemajuan suatu lembaga pendidikan yang dipimpinnya.

Guru adalah tenaga pendidik yang professional yang menjadi tulang punggung dan sebagai garda terdepan kemajuan suatu pendidikan disuatu sekolah, mengingat gurulah yang berhadapan langsung dengan para siswa/peserta didik didepan kelas maupun diluar kelas. Kepala sekolah adalah guru yang diberi tugas tambahan sebagai kepala sekolah namun peran dan fungsi seorang kepala sekolah dalam mempersiapkan kualitas out put maupun out come, dibutuhkan seorang kepala sekolah yang memiliki gaya dan model

Pengaruh Budaya Organisasi Dan Kepemimpinan Kepala Sekolah Terhadap Komitmen Organisasi Serta Dampaknya Terhadap Kinerja Guru SMK Muhammadiyah Salatiga (Samtono) 
kepemimpinan yang transformasional,Visioner, inofatif dan kreatif serta membawa perubahan sekolah guna mewujudkan visi dan misi sekolah.

Menururt Robbin, ( 2002 ) kepemimpinan adalah kemampuan untuk memepengaruhi suatu kelompok kearah tercapainya tujuan. Setiap manusia pada hakikatnya adalah pemimpin dan setiap manusia akan diminta pertanggungjawabannya atas kepemimpinannya kelak. Sedangkan Usman, (2010) menyebutkan fungsi manajemen dengan singkatan POLC, yaitu Planning, Organizing, Leading, dan Controlling. Alasannya dengan melalui POLC para pemimpin dapat mengarahkan perencanaan, pengorganisasian, pelaksanaan dan pengendalian dengan baik. Selanjutnya Priansa, ( 2014 ) memberikan pengertian Kepemimpinan kepala sekolah adalah kemampuan dan kompetensi baik hard skills maupun soft skills untuk mempengaruhi seluruh sumber daya sekolah agar mampu mencapai tujuan dan sasaran yang telah ditetapkan sekolah. Dari beberapa penjelasan tersebut diatas pada prinsipnya kepemimpinan kepala sekolah yang dituntut adalah kepemimpinan kepala sekolah yang efektif. Kepemimpinan kepala sekolah yang efektif adalah kepemimpinan yang mampu memberikan inspirasi dan teladan yang baik bagi guru, staf, dan pegawai lainnya serta memberikan kepuasan bagi para stakeholders sekolah.

\section{Budaya Organisasi}

Istilah budaya organisasi ( BO ) dan budaya Perusahaan ( BP ) adalah salinan bahasa inggris Organizational Culture ( OC ) dan Corporate Culture ( CC ). Budaya dari bahasa latin colere yang berarti mengolah, mengerjakan, terutama mengolah tanah atau bertani, sedangkan dalam bahasa inggris disebut culture (Umam, 2010)

Budaya dalam konteks komunitas, baik dalam bentuk kelompok, organisasi, suku bangsa, atau Negara Negara sebagai pengikat atau perekat hingga terbentuk suatu kesatuan yang utuh sebagai suatu kelompok, organisasi, suku, bahkan Negara. Setiap organisasi yang dibentuk telah menetapkan suatu tujuan tertentu sebagai pedoman dalam menjalankan organisasi.

Selanjutnya Stephen dkk dalam Hanggraeni ( 2011 ) Organizational Culture sering disebut kultur organisasi, dan menjadi lebih popular dengan sebutan Budaya Organisasi. Dan diefinisikan sebagai sebuah system makna bersama yang dianut oleh para anggota 
yang membedakan suatu organisasi dari organisasi organisasi lainnya. Selanjutnya kultur organisasi atau budaya organisasi disini lebih ditekankan pada budaya organisasi sekolah yang lazim dinamakan dengan budaya sekolah khususnya yang ada di SMK Muhammadiyah Salatiga.

3. Komitmen Organisasi.

Sofiah ( 2008 ), mendefinisikan komitmen organisasi sebagai rasa identifikasi ( kepercayaan terhadap nilai-nilai organisasi), keterlibatan ( kesediaan untuk berusaha sebaik mungkin demi kepentingan organisasi ) dan loyalitas ( keinginan untuk tetap menjadi anggota organisasi yang bersangkutan ) yang dinyatakan oleh seorang pegawai terhadap organisasinya. Selanjutnya Robbins ( 2003 ), memberikan definisi komitmen organisasi sebagai suatu keadaan dimana seoang individu memihak organisasi serta tujuan-tujuan dan keinginannya untuk mempertahankan keanggotaannya dalam organisasi. Dari dua definisi tersebut dapat diambil garis besarnya bahwa, pembahasan tentang komitmen organisasi identik dengan membahas permasalahan tanggung jawab terhadap organisasi, seorang guru yang memiliki komitmen yang tinggi terhadap organisasi berarti guru tersebut memiliki tanggung jawab yang tinggi pula terhadap organisasi kelembagaan pendidikan SMK Muhammadiyah, sebaliknya semakin rendah guru memiliki komitmen organisasi berarti semakin rendah pula tanggung jawabnya terhadap lembaga organisasi pendidikan di SMK Muhammadiyah.

\section{Kinerja Guru}

Menurut Umam ( 2010 ), kinerja adalah catatan mengenai akibat-akibat yang dihasilkan pada sebuah fungsi pekerjaan atau aktivitas selama periode tertentu yang berhubungan dengan tujuan organisasi. Selanjutnya Dirjen PMPTK Kemendiknas ( 2008 ) menjelaskan Indikator penilaian terhadap kinerja guru dilakukan terhadap tiga kegiatan dikelas yaitu: a. Perencanaan Program Kegiatan Pembelajaran, b. Pelaksanaan Kegiatan Pembelajaran, c. Pelaksanaan Evaluasi/Penilaian Pembelajaran.

Dari pengertian tersebut diatas dapat disimpulkan bahwa kinerja guru adalah hasil kerja yang dicapai seseorang, dimana dilaksanakan atas tugas dan tanggung jawabnya masingmasing sesuai dengan keahliannya untuk bersama-sama memajukan organisasi dan tidak melanggar ketentuan hukum serta etika didalam pelaksanaannya, kinerja juga merupakan 
semua perilaku sebagai ungkapan kemampuan yang didasari oleh pengetahuan (knowledge), sikap (attitude), dan ketrampilan (skill)

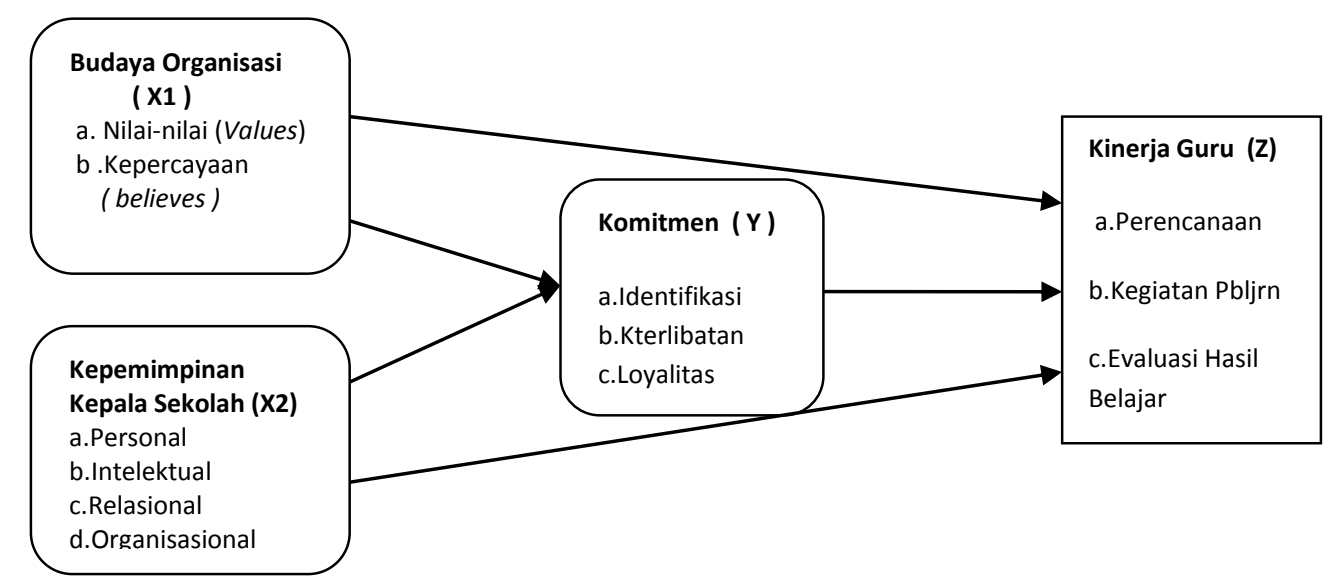

Gambar 1

\section{Kerangka Pemikiran Teorities}

\section{Hipotesis Penelitian}

Berdasarkan rumusan masalah dan tujuan penelitian tersebut di atas, maka diajukan Rumusan Hipotesis sebagai berikut :

1. Terdapat pengaruh positif dan siqnifikan budaya organisasi terhadap komitmen organisasi di SMK Muhammadiyah Salatiga

2. Terdapat pengaruh yang positif dan siqnifikan kepemimpinan sekolah terhadap komitmen organisasi di SMK Muhammadiyah Salatiga

3. Terdapat pengaruh yang positif dan siqnifikan budaya organisasi tehadap kinerja guru SMK Muhammadiyah Salatiga.

4. Terdapat pengaruh yang positif dan siqnifikan kepemimpinan kepala sekolah terhadap kinerja guru di SMK Muhammdiyah Salatiga.

5. Terdapat pengaruh yang posistif dan siqnifian komitmen organisasi terhadap kinerja guru SMK Muhammadiyah

6. Komitmen organisasi memediasi budaya organisasi terhadap kinerja guru SMK Muhammmah Salatiga

7. Komitmen organisasi memediasi Kepemimpinan kepala sekolah terhadap kinerja guru SMK Muhammadiyah Salatiga.

\section{METODE PENELITIAN}

1. Jenis Penelitian 
Jenis penelitian disini penulis menggunakan pendekatan kuantitatif jenis survey, Menurut Arikunto ( 2010 ) Analisis kuantitatif yaitu digunakan untuk menguji teori, menguji hipotesis, menggunakan alat uji statisti karena menekankan menggunakan angka mulai pengumpulan data, penafsiran data tersebut serta penamnpilan dari hasilnya.

2. Lokasi Penelitian

Kegiatan penelitian dilaksanakan pada SMK Muhammadiyah Salatiga pada tahun 2017, yang dimulai bulan Februari 2017 sampai dengan bulan Juli 2017.

3. Teknik Sampling

Teknik pengambilan sampel digunakan teknik sensus, artinya semua anggota populasi diambil untuk dijadikan sampel seluruhnya Arikunto ( 2010 ). Dalam penelitian disini penulis mengambil sampel sebanyak 65 orang guru SMK Muhammadiyah Salatiga, kecuali Kepala Sekolah yang tidak dipilih menjadi sampel dalam penelitian.

\section{Alat Pengumpul Data}

Alat yang digunakan untuk pengumpulan data meliputi : a. Studi Dokumentasi, yaitu dokumentasi nama-nama guru SMK Muhammadiyah Salatiga, b. Kuesioner/Angket sebagai instrumen yang harus dijawab oleh responden guru-guru SMK Muhammadiyah Salatiga dan, c. Observasi untuk mengamati baik langsung maupun tidak langsung terhadap guru-guru SMK Muhammadiyah Salatiga.

\section{ANALISIS DATA DAN PEMBAHASAN}

\section{Regresi Beranda}

\section{Persamaan I}

\section{Tabel 1}

\section{Hasil Analisis Regresi Linier Berganda}

Coefficients

\begin{tabular}{|c|c|c|c|c|c|}
\hline \multirow[b]{2}{*}{ Model } & \multicolumn{2}{|c|}{ Unstandardized Coefficients } & $\begin{array}{l}\text { Standardized } \\
\text { Coefficients }\end{array}$ & \multirow[t]{2}{*}{$\mathrm{t}$} & \multirow[t]{2}{*}{$\mathrm{Siq}$} \\
\hline & $\mathrm{B}$ & Std Error & Beta & & \\
\hline (Contant) & 12.713 & 3,304 & & 3,847 & 000 \\
\hline X1 Budaya Or & 609 & ,133 & ,552 & 4,575 &, 000 \\
\hline $\begin{array}{l}\text { X2 Kepimpin } \\
\text { an Kep Sek }\end{array}$ &, 149 & ,205 & ,088 & ,727 & , 470 \\
\hline
\end{tabular}

\section{a.Dependent Variable : Y KOMIT}

Berdasar hasil analisis regresi linier berganda yang diperoleh maka dibuat persamaan berganda sebagai berikut : 
$Y=\beta_{1} \cdot X_{1}+\beta_{2} \cdot X_{2}$

$Y=0,552 X_{1}+0,088 X_{2}$

Persamaan Linier Berganda tersebut dapat disimpulkan :

1. Koefisien regresi menunjukkan bahwa variable Budaya Organisasi memiliki nilai beta positif 0,552 . Hal ini menunjukkan bahwa semakin baik budaya organisasi yang dimiliki semakin meningkatkan komitmen guru.

2. Koefisien regresi menunjukkan bahwa variable kepemimpinan kepala sekolah memiliki nilai beta positif sebesar 0,088 . Hal ini menunjukkan bahwa semakin baik kepemimpinan akan meningkatkan komitmen guru.

\section{Persamaan II}

Analisis regresi dalam penelitian ini digunakan untuk mengetahui pengaruh budaya organisasi, kepemimpinan kepala sekolah dan komitmen terhadap kinerja guru, diperoleh hasil regresi sebagai berikut :

\section{Tabel 2}

Hasil Analisis Regresi Linier Berganda Coefficients $^{\mathrm{a}}$

\begin{tabular}{|c|c|c|c|c|c|}
\hline \multirow[b]{2}{*}{ Model } & \multicolumn{2}{|c|}{ Unstandardized Coefficients } & $\begin{array}{l}\text { Standardized } \\
\text { Coefficients }\end{array}$ & \multirow[t]{2}{*}{$\mathrm{t}$} & \multirow[t]{2}{*}{ Siq } \\
\hline & B & Std Error & Beta & & \\
\hline (Contant) & 4,252 & 3,795 & & 1,121 & 267 \\
\hline X1 Budaya Or & ,588 & ,159 & ,401 & 3,694 &, 001 \\
\hline X2 Kepimpinan & , 192 & ,211 & 085 & ,727 & ,367 \\
\hline Kep Sek & & & & & \\
\hline Y Komitmen & ,583 & ,136 & ,438 & 4,303 & ,000 \\
\hline
\end{tabular}

a.Dependent Variable : Z. Kinerja

$Z=\beta_{1 . .} X+\beta_{2 .} . X+\beta_{3} . Y$

$Z=0,401 X_{1}+0,085 X_{2}+0,438 Y$

Persamaan linier berganda tersebut dapat disimpulkan :

1. Koefisien egresi menunjukkan bahwa variable Budaya organisasi memiliki nilai beta sebesar positif 0,401. Hal ini menunjukkan bahwa semakin baik budaya organisasi yang dimiliki akan meningkatkan kinerja guru.

2. Koefisien regresi menunjukkan bahwa variable kepemimpinan kelapa sekolah memiliki nilai beta positif sebesar 0,085 . Hal ini menunjukkan bahwa semakin 
baik kepemimpinan kepala sekolah yang dimiliki maka semakin meningkatkan kinerja guru.

3. Koefisien regresi menunjukkan bahwa komitmen memiliki beta positif sebesar 0,438. Hal ini menunjukkan bahwa semakin tinggi komitmen akan semakin meningkatkan kinerja guru.

\section{Uji Model}

\section{Uji Model Persamaan I}

Uji Anova atau uji $\mathrm{F}$ adalah uji statistik yang fungsinya untuk mengetahui apakah variabel independen budaya organisasi dan kepemimpinan kepala sekolah merupakan model persamaan yang tepat untuk mengukur perubahan variabel komitmen. Dari olah data diperoleh hasil sebagai berikut :

\section{Tabel 3}

Uji F

ANOVA ${ }^{a}$

\begin{tabular}{|cl|l|l|r|r|r|}
\hline Model & $\begin{array}{l}\text { Sum of } \\
\text { Squares }\end{array}$ & & Df & Mean Square & F & Sig \\
\hline 1 & $\begin{array}{l}\text { Regression } \\
\text { Residual } \\
\text { Total }\end{array}$ & 135,742 & 2 & 67,871 & \\
& 242,591 & 57 & 4,256 & 15,947 &, $000 \mathrm{a}$ \\
& 378,333 & 59 & & & \\
\hline
\end{tabular}

\section{a.Predictors: (Contant), X2.Kepemimpinan, X1.Budaya}

b.Dependent Variabel : Y.Komitmen

Pengujian pada tabel tersebut dapat disimpulkan sebagai berikut: Data di atas menunjukkan bahwa F hitung sebesar 15,947 dengan nilai Sig 0,000 < 0,05. Variabel budaya organisasi ( X1 ) dan Kepemimpinan sekolah ( X2 ) merupakan variabel yang baik dan tepat ( Fit ) untuk mengukur perubahan dalam variabel komitmen organisasi ( Y ), sehingga membentuk persamaan yang fit

\section{Uji Koefisien Determinasi ( Uji $\mathbf{R}^{2}$ )}

Koefisien determinasi atau adjusted $R$ square digunakan untuk mengetahui seberapa pengaruh variabel bebas (indevedent variable ). Hasil analisis diperoleh nilai koefisien determinan seperti berikut:

Pengaruh Budaya Organisasi Dan Kepemimpinan Kepala Sekolah Terhadap Komitmen Organisasi Serta Dampaknya Terhadap Kinerja Guru SMK Muhammadiyah Salatiga (Samtono) 
Tabel 4

Hasil Analisis Koefisien Determinasi

Model Summary

\begin{tabular}{|l|c|c|c|c|}
\hline Model & R & R Square & $\begin{array}{c}\text { Adjusted R } \\
\text { Square }\end{array}$ & $\begin{array}{l}\text { Std.Error of } \\
\text { the Estimate }\end{array}$ \\
\hline 1 &, $599^{\mathrm{a}}$ &, 359 &, 336 & 2,06300 \\
\hline
\end{tabular}

a. Predictors : (Constant), X2 Kepemimpian, X2 Budaya.

Dari tabel tersebut diatas dapat disimpukan bahwa, Hasil perhitungan estimasi regresi diperoleh nilai koefisien determinasi (Adjusted $R$ Square) sebesar 0,336 atau 33,6\% perubahan pada variabel dependen komitmen organisasi ( Y ) dapat dijelaskan oleh perubahan dalam variabel indevenden budaya organisasi (X1) dan kepemimpinan kepala sekolah (X2), sedangkan sisanya sebesar $66,4 \%$ diterangkan oleh variabel yang tidak diajukan atau dijelaskan dalam model penelitian ini.

\section{Uji Model Persamaan II}

Uji Anova atau uji $\mathrm{F}$ adalah uji statistik yang fungsinya untuk mengetahui apakah variabel independen budaya organisasi, kepemimpinan kepala sekolah, dan komitmen organisasi merupakan model persamaan yang tepat untuk mengukur perubahan variabel dependennya yaitu kinerja guru. Dari olah data diperoleh hasil sebagai berikut :

Tabel 5

Hasil Uji Anovab

\begin{tabular}{|c|c|c|c|c|c|}
\hline Model & Sum of Squares & df & Mean Square & $\mathrm{F}$ & Sig. \\
\hline Regression & 420,135 & \multirow[b]{3}{*}{56} & 140,045 & \multirow{4}{*}{31,431} & \multirow[t]{4}{*}{, $000^{\mathrm{a}}$} \\
\hline Residual & 249,515 & & 4,456 & & \\
\hline Total & 669,650 & & & & \\
\hline & & 59 & & & \\
\hline
\end{tabular}

a. Predictor : Contant) Y Komit, X2 Kepemimpinan X1 Budaya Organisasi

b. Dependen Variable : ZKinerja Guru

Pengujian pada tersebut diatas dapat disimpulkan sebagai berikut : Data di atas menunjukkan bahwa $\mathrm{F}$ hitung sebesar 31,43 dengan nilai sig 0,000 $<0,05$. Variabel budaya organisasi (X1), kepemimpinan kepala sekolah (X2) dan komitmen organisasi ( Y ) merupakan variabel yang baik dan (fit) untuk mengukur perubahan dalam variabel kinerja guru ( $\mathrm{Z}$ ) sehingga nenbentuk persamaan yang fit. 


\section{Uji Koefisien Determinasi ( Uji $\mathbf{R}^{2}$ )}

Koefisien determinasi atau adjusted $R$ Square digunakan untuk mengetahui seberapa pengaruh variabel bebas ( devendent variable ). Hasil analisis diperoleh nilai koefisien determinasi sebagai berikut :

Tabel 6

Hasil Analisis Koefisien Determinasi

Model Summary

\begin{tabular}{|l|c|c|c|c|}
\hline Model & \multicolumn{1}{|c|}{$\mathrm{R}$} & $\mathrm{R}$ Square & $\begin{array}{c}\text { Adjusted R } \\
\text { Square }\end{array}$ & $\begin{array}{c}\text { Std Error of } \\
\text { The } \\
\text { Estimate }\end{array}$ \\
\hline 1 &, $792^{\mathrm{a}}$ &, 627 &, 607 & 2,11083 \\
\hline
\end{tabular}

a. Predictors : (Contant), Y Komit, X2 Kepemimpinan, X1 Budaya.

Dari tabel tersebut diatas dapat disimpulkan bahwa hasil perhitungan estimasi regresi diperoleh nilai koefisien determinasi (Adjusted $R$ Square) sebesar 0,607 atau $60,7 \%$ perubahan pada variabel dependen kinerja guru ( $\mathrm{Z}$ ) dapat dijelaskan oleh perubahan dalam variabel indevenden budaya organisasi ( X1 ), kepemimpinan kepala sekolah ( X2 ) serta komitmen organisasi ( Y ), sedangkan sisanya sebesar $39,3 \%$ diterangkan oleh variabel lain yang tidak diajukan atau dijelaskan dalam model penelitian ini.

\section{Pengujian Hipotesis}

\section{Uji t ( pengaruh parsial )}

Uji parsial digunakan untuk menguji hipotesis adanya pengaruh variabel independen terhadap variabel dependen secara sendiri-sendiri.

Dengan taraf siqnifikansi a $=0,05$

1. Pengujian hipotesis pertama

Menguji pengaruh budaya organisasi terhadap komitmen organisasi. Diperoleh nilai koefisien beta positif sebesar 0,552 dan nilai siqnifikansi sebesar $0,000<$ dari 0,05 . Hal ini mengindikasikan hipotesis pertama diterima. Artinya budaya organisasi berpengaruh secara positif dan siqnifikan terhadap komitmen organisasi.

Pengaruh Budaya Organisasi Dan Kepemimpinan Kepala Sekolah Terhadap Komitmen Organisasi Serta Dampaknya Terhadap Kinerja Guru SMK Muhammadiyah Salatiga (Samtono) 
2. Pengujian hipotesis kedua

Menguji pengaruh kepemimpinan kepala sekolah terhadap komitmen organisasi.

Diperoleh koefisien beta positif sebesar 0,088 dengan nilai siqnifikansi sebesar $0,470>0,05$, hal ini mengindikasi hipotesis kedua ditolak/tidak diterima. Artinya kepemimpinan kepala sekolah tidak berpengaruh secara siqnifikan terhadap komitmen organisasi.

3. Pengujian hipotesis ketiga

Menguji pengaruh budaya organisasi terhadap kinerja guru. Diperoleh koefisien beta positif sebesar 0,401 dengan nilai siqnifikansi sebesar $0,001<$ dari 0,05 . Hal ini mengindikasikan hipotesis ketiga diterima. Artinya budaya organisasi berpengaruh terhadap kinerja guru.

4. Pengujian hipotesis kempat

Menguji pengaruh kepemimpinan kepala sekolah terhadap kinerja guru. Diperolah koefisien beta positif sebesar 0,085 dengan nilai siqnifikansi sebesar 0,367 > dari 0,05. Hal ini mengindikasikan hipotesis keempat ditolak/tidak diterima. Artinya kepemimpinan kepala sekolah tidak berpengaruh terhadap kinerja guru.

5. Pengujian hipotesis kelima

Menguji pengaruh komitmen organisasi terhadap kinerja guru. Diperoleh koefisien beta positif sebesar 0,438 dengan nilai siqnifikansi sebesar $0,000<$ dari 0,05. Hal ini mengindikasikan hipotesis kelima diterima. Artinya komitmen mempunyai pengaruh terhadap kinerja guru.

\section{Uji Efek Mediasi}

Hasil Uji mediasi komitmen organisasi dalam pengaruh budaya organisasi terhadap kinerja guru.

Pada hasil uji pengaruh budaya organisasi terhadap kinerja guru dimediasi komitmen organisasi dapat dinyatakan pada gambar sebagai berikut : 


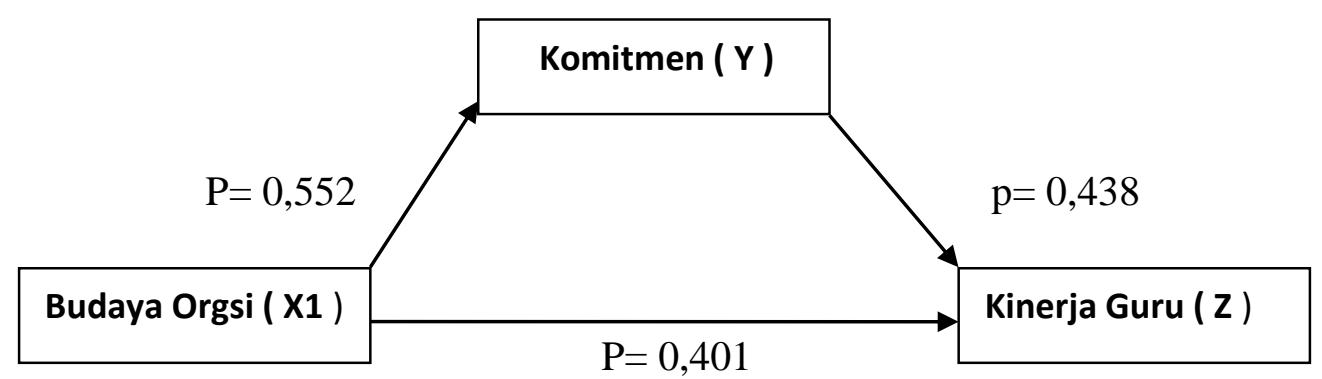

Gambar 2

Model Mediasi

Hasil pengujian :

Hubungan Langsung $\mathrm{p}=0,401$

Hubungan Tidak Langsung 0,552 x 0,438 =0,242

Karena Hubungan langsung ( 0,401 ) > dari Hubungan Tidak Langsung ( 0,242 )

maka tidak ada mediasi. budaya organisasi lebih berdampak secara langsung memperngaruhi kinerja guru, dari pada melalui komitmen.

Hasil Uji Mediasi Komitmen organisasi dalam pengaruh kepemimpinan kepala sekolah terhadap kinerja guru

Pada hasil uji pengaruh kepemimpinan kepala sekolah terhadap kinerja guru dimediasi komitmen dapat dinyatakan pada gambar sebagai berikut :

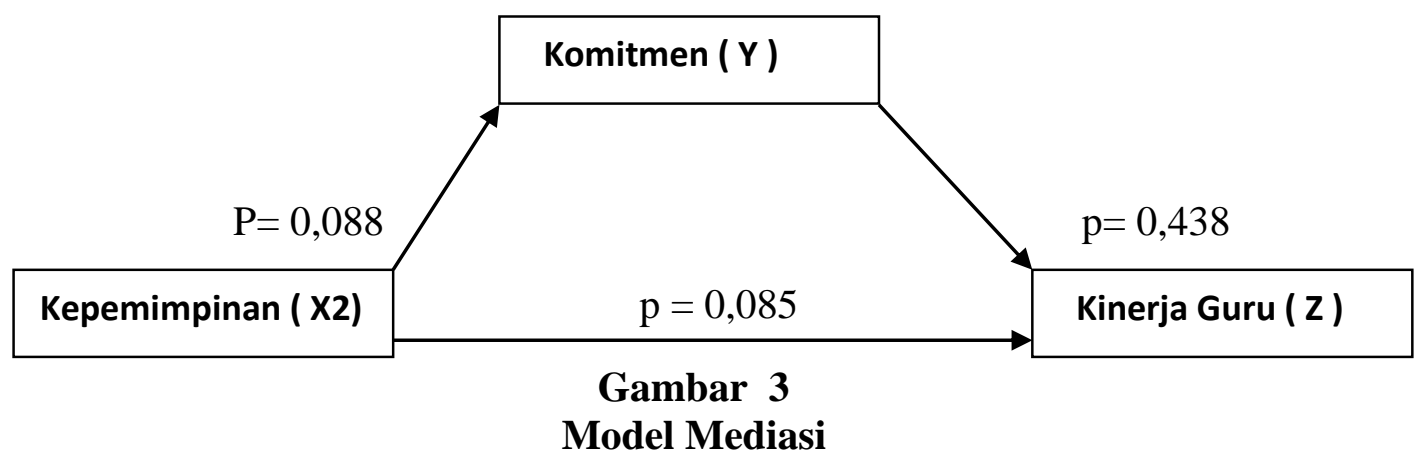

Hasil Pengujian :

Hubungan Langsung $\mathrm{p}=0,085$

Hubungan Tidak Langsung 0,088 x 0,438 = 0,039

Pengaruh Budaya Organisasi Dan Kepemimpinan Kepala Sekolah Terhadap Komitmen Organisasi Serta Dampaknya Terhadap Kinerja Guru SMK Muhammadiyah Salatiga (Samtono) 
Karena Hubungan Langsung ( 0,085 ) > dari Hubungan Tak Langsung ( 0,039 ), maka tidak ada mediasi, kepemimpinan Kepala Sekolah lebih berdampak dan secara langsung berpengaruh pada kinerja guru dibandingkan melalui komitmen.

\section{SIMPULAN DAN SARAN.}

\section{Simpulan}

Berdasarkan hasil analisa data tersebut di atas akhirnya dapat disimpulan sebagai berikut :

1. Budaya organisasi berpengaruh terhadap komitmen organisasi, artinya semakin banyak para guru SMK Muhammadiyah untuk memahami secara mendalam akan nilai-nilai organisasi dan memiki kepercayaan yang mantab dan yakin akan organisasi Kemuhammadiyahan maka akan semakin memantabkan pada komitmen organisasi.

2. Kepemimpinan kepala sekolah tidak berpengaruh terhadap komitmen organisasi, artinya para guru sudah memahami dan mendalami akan peran dan fungsi dari suatu organisasi yang sudah dipercaya secara bulat akan nilai-nilai yang ada dalam tujuan organisasi maka mereka tidak begitu memperhatikan peran dan fungsi kepemimpinan kepala sekolah.

3. Budaya organisasi berpengaruh terhadap kinerja guru, artinya para guru makin menyadari sepenuhnya akan tujuan organisasi yang akan dicapai, dengan sendirinya guru akan memperbaiki kinerja guru dalam rangka mencapai tujuan organisasi.

4. Kepemimpinan kepala sekolah tidak berpengaruh terhadap kinerja guru, artinya mengingat guru sudah memiliki komitmen akan nilai-nilai dan kepercayaan terhadap organisasi, sehingga guru merasa peran kepemimpinan kepala sekolah tidak menjadi perhatian yang serius serta tidak menjadi suatu opsi prioritas.

5. Komitmen organisasi berpengaruh terhadap kinerja guru, artinya guru memahami akan fungsi dan peran organisasinya serta menjadi bagian dari 
tanggung jawab sebagai anggota organisasi, dengan sendirinya guru akan bertanggung jawab akan profesinya untuk meningkatkan kualitas kinerjanya.

6. Budaya organisasi berdampak secara langsung terhadap kinerja guru, tanpa dimediasi oleh komitmen organisasi, artinya hipotesis keenam bisa diterima. Sekolah yang sudah memiliki budaya organisasi yang baik dan dinamis maka anggotanya akan bertanggung jawab terhadap organisasinya yang diwujudkan dan diaktualisasikan dalam bentuk kinerja guru.

7. Kepemimpinan kepala sekolah berdampak secara langsung terhadap kinerja guru tanpa dimediasi oleh komitmen organisasi, artinya hipotesis ketujuh bisa diterima. Kepala sekolah lebih memerankan akan peran manejerialnya sebagai seorang pemimpin dalam rangka menyelamatkan lembaga pendidikan SMK yang dipimpinannya dengan segala cara yang ditempuh untuk memperbaiki kinerja guru dalam rangka mencapai target yang telah disepakati bersama dengan dewan guru dan yang terkait.

\section{Saran-saran.}

1. Budaya organisasi lebih dominan dan berpengaruh pada komitmen serta berdampak secara langsung mempengaruhi kinerja guru, maka dipandang perlu dari lembaga organisasi kemuhammadiyahan secara terprogram dan berkelanjutan lewat pembinaan dan pemahaman organisasi secara sistematis dan dinamis untuk membina anggota organisasi secara betanggung jawab akan visi dan misi yang telah terbangun secara baik dan perlu ditingkatkan secara bertahap dan terukur lewat sekolah-sekolah binaan khususnya SMK Muhammadiyah.

2. Kepemimpinan kepala sekolah tidak memiliki pengaruh terhadap komitmen organisasi, namun kepemimpinan kepala sekolah berdampak secara langsung berpengaruh pada kinerja guru tanpa mediasi dari variabel komitmen. Untuk itu dipandang perlu penekanan peran dan fungsi kepala sekolah dapat memerankan peran dan fungsinya secara maksimal lewat program peningkatan pengelolaan sekolah menengah kejuruan lazim dinamakan dengan EMASLIM, artinya 
seorang kepala sekolah sebagai ( Edukator, Manajer, Administrator, Supervisor, Lider, Inovaor, dan Motivator )

3. Komitmen organisasi berpengaruh terhadap kinerja guru, maka dipandang perlu peran dan fungsi kepala sekolah untuk bisa menggerakkan anggota organisasi khususnya guru SMK Muhammadiyah untuk bisa meningkatkan kualitas kompetensi profesional, seperti mengikut sertakan kegiatan-kegiatan Bintek ( Bimbingan teknis), Pelatihan-pelatian, maupun IHT ( In house tranning ) secara terprogram dan secara berkelanjutan.

4. Guna peningkatan kualitas pendidikan di SMK Muhammadiyah lewat peningkatan kinerja guru dipandang perlu semua anggota organisasi khususnya guru SMK Muhammadiyah perlu dibangun secara konseptual tentang pemahaman yang mendalam dan utuh tentang Kemuhammadiyahan, dengan harapan bisa terbentuk dan terebangun karakter masing-masing pribadi anggota organisasi muhamadiyah, yang kedepan terbentuk komitmen yang tinggi dan memiliki loyalitas yang tinggi pula terhadap organisasinya.

\section{DAFTAR PUSTAKA}

Arikunto.S. ( 2010 ), Prosedur Penelitian : Suatu Pendekatan Praktik, Rineka Cipta, Jakarta

Anoraga Panji, ( 2009 ), Psikologi Kerja, Rinaka Cipta, Jakarta,

Daryanto, ( 2013 ), Standar Kompetensi dan Penilaian Kinerja Guru Profesional,Gava Media,Yogyakarta

Dewi Hanggraeni, ( 2011 ), Perilaku Organisasi Teori, Kasus, Dan Analisis, Pnbt: Fakultas Ekonomi Universitas Indonesia, Jakarta.

Direktorat Jendral PMTK, ( 2008 ), Sertifikasi Guru Dalam Jabatan Tahun 2008: Pedoman Sertifikasi Guru Dalam Jabatan Melalui Penilaian Portofolio, Depdiknas, Jakarta.

Departemen Pendidikan Nasional RI, ( 2003 ). Undang-Undang RI Nomor 20 Tahun 2003, Tentang Sistem Pendidikan Nasional, Depdiknas, Jakarta.

Departemen Pendidikan asional ( 2015 ), Undang-Undang RI Nomor 14 Tahun 2005, Tentang Guru dan Dosen, Depdiknas, Jakarta. 
Handoko, ( 2011 ), Manajemen Edisi 2, Badan Penerbit Fakultas Ekonomi UGM, Yogyakarta

Khoerul, Umam. ( 2010 ) Perilaku Organisasi, CV. Pustaka Setia, Bandung

Priansa, Rismi Somad, ( 2014 ), Manajemen Supervisi \& Kepemimpinan Kepala Sekolah, Alfabeta, Bandung.

Robbins, S.P, ( 2008 ), Perilaku Organisasi : Konsep, Kontroversi, dan Aplikasi. Aliha Bahasa oleh Pujaatmaja Hadyana. PT. Prehallindo, Jakarta.

Salusu, ( 2010 ), Pengambilan Keputusan Stratejik Untuk Organisasi Publik dan Organisai Nonprofit. PT. Gramedia Widiasarana Indonesia, Jakarta.

Sugiyono, ( 2009 ), Statistik Untuk Penelitian, Alfabeta Bandung

Sofiah, ( 2008 ), Perilaku Organisasi, Andi, Yogyakarta

Usman, Moh, Uzer, ( 2007 ), Menjadi Guru Profesional. Remaja Rusdakarya, Bandung.

Veithzal, Rivai, ( 2009 ), Kepemimpinan Dan Perilaku Organisasi, Edisi Kedua, Raja Grafindo Persada, Jakarta.

Pengaruh Budaya Organisasi Dan Kepemimpinan Kepala Sekolah Terhadap Komitmen Organisasi Serta Dampaknya Terhadap Kinerja Guru SMK Muhammadiyah Salatiga (Samtono) 